\title{
Levee development along tidal channels
}

\author{
M. van der Wegen ${ }^{1}$, J. Guo ${ }^{1}$, B.E. Jaffe ${ }^{2}$, A.J.F. van der Spek ${ }^{1,3,4}$ and J.A. Roelvink ${ }^{1,3,4}$ \\ ${ }^{1}$ Water Science and Engineering, UNESCO-IHE, Delft, the Netherlands \\ ${ }^{2}$ USGS Pacific Science Center, Santa Cruz, California, USA. \\ ${ }^{3}$ Delft University of Technology, Delft, the Netherlands. \\ ${ }^{4}$ Deltares, Delft, the Netherlands.
}

\begin{abstract}
Levees are small elevation ridges found on the edge between channels and shoals. They are known to develop along river channels during floods and along channels in alluvial deep water fans. Levees in tidal environments such as the Waddenzee are less pronounced (with a typical height in the order of $10 \mathrm{~cm}$ ) and may be recognized by the fact that they become dry earlier than the surrounding mudflats, due to their higher elevation and coarser material. Levees form an essential link in the morphological interaction between tidal channels and shoals, although their development is yet poorly understood and requires further research.

We explore levee development by a process-based approach (Delft3D) both under highly schematized conditions and a realistic case study. The schematized approach concerns morphological development of a $2 \mathrm{~km}$ long $100 \mathrm{~m}$ wide tidal channel with surrounding tidal flats. The levees develop during flood and further analysis shows the sensitivity to model parameters such as the diffusion coefficient, shoal width, grain size, and initial channel depth. The realistic case study concerns a tidal channel in a sub-embayment of San Francisco Estuary. 150 Years of bathymetric observations are coupled to a process-based morphodynamic modeling exercise explaining the levee development. Model results of the schematized setup and teh San Pablo Bay case have in common that major accreation of the levees and the channel slopes occurs during flooding conditions.
\end{abstract}

\section{INTRODUCTION}

Levees are small elevation, coarse material ridges found on the edge between channels and shoals. They are known to develop along river channels during floods [Adams et al., 2004, Rowland et al., 2009, Brierley et al, 1997], along channels in alluvial deep water fans during high turbidity flow events [Normark et al.,2002, Fildani et al., 2006, Straub and Mohrig, 2008], and along creek systems in salt marshes and mudflats during regular tidal forcing [Perillo and Iribarne, 2003, Temmerman et al., 2005, Wells et al., 1990].

Levees in tidal environments such as the Waddenzee are less pronounced (with a typical height in the order of $10 \mathrm{~cm}$ ) and may be recognized by the fact that they become dry earlier than the surrounding mudflats, due to their higher elevation and coarser material. In a muddier environment Jaffe et al. [2007] report continuous measured narrowing of the tidal channel in San Pablo Bay over 150 years which may be interpreted as an expansion of the intertidal mudflats. Accretion takes place at the steep slope between channel and shoal, rather than at the edge of the shoal itself. It is not clear whether or not levee development and slope accretion are governed by similar processes and to what extent the sediment characteristics play a role in these types of channel shoal interaction.

\section{AIM AND METHODOLOGY}

Levee development forms an essential part in the morphodynamic interaction between channels and shoals although the governing processes are yet poorly understood and require further research. The aim of the current work is to investigate channel shoal interactions in more detail. Use is made of a process-based numerical model (Delft3D).

Delft 3D solves the Reynolds averaged Navier Stokes equations, including the $\mathrm{k}-\varepsilon$ turbulence closure model, and applies a horizontal curvilinear grid with sigma layers for vertical grid resolution. It allows for salt-fresh water density variations, separate formulae for mud transport and sand transport, and variations in bed composition and specification (for example, bed layers with different percentages of mud and sand and spatial variation of critical shear stress). The impact of wind and waves can be added, so that, for example, the effects of wind set up and increased shear stress due to waves are taken into account. The applied wave model is SWAN of which a detailed description and its application in Delft 3D can be found respectively at the SWAN homepage (http://vlm089.citg.tudelft.nl/swan/index.htm), Booij et al. (1999) and Lesser et al. (2004). For every hydrodynamic time step ( 1 minute in this case) the flow module calculates water levels and velocities from the shallow water equations. Based on these hydrodynamic conditions and the wind field, the wave module calculates a wave field every hour and adds wave induced shear stresses to the shear stresses calculated from the flow module. The wave field is considered to be constant during one hour. Sediment transport is calculated from the resulting flow field and the bed is updated based on the divergence of the sediment transport field [Roelvink, 2006].

Our first step is to investigate channel shoal interaction under (very) schematized circumstances, i.e. by means of a $2 \mathrm{~km}$ long channel forced by tidal flow and additional sensitivity analysis on input parameters and processes. We will subsequently relate the outcome of the schematized model to a case study, i.e. San Pablo Bay, California, USA [Van der Wegen et al, 2010, 2011]. 


\section{MODEL SETUP}

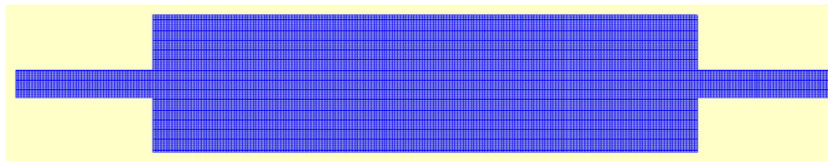

Figure 1. Model grid for schematized conditions

\section{Schematised model}

Figure 1 shows the grid applied for the schematized model. The grid cell size is $10 \mathrm{~m}$ in transverse direction and $5 \mathrm{~m}$ in longitudinal direction. The channel has a width of the boundary limits. In the wider middle part of the model domain the channel is flanked by shoals. We suppose that the tide propagates from left to right. The boundary conditions on the west side and the eastside are described by a tidally varying water level with an amplitude of $1.75 \mathrm{~m}$ and a period of 12 hours with a small water level phase difference between the boundaries to drive the tidal current defined by

$$
\Delta \varphi=\frac{360^{\circ}}{T \sqrt{g h}} L
$$

in which $\mathrm{T}(\mathrm{s})$ is the tidal period, $\mathrm{g}\left(\mathrm{m} / \mathrm{s}^{2}\right)$ is the gravitational acceleration, $\mathrm{L}$ is the length of the model grid (m), $\mathrm{h}$ is the initial water depth in the channel (m). The standard settings apply Van Rijn transport formulations with constant D50.

\section{San Pablo Bay model}

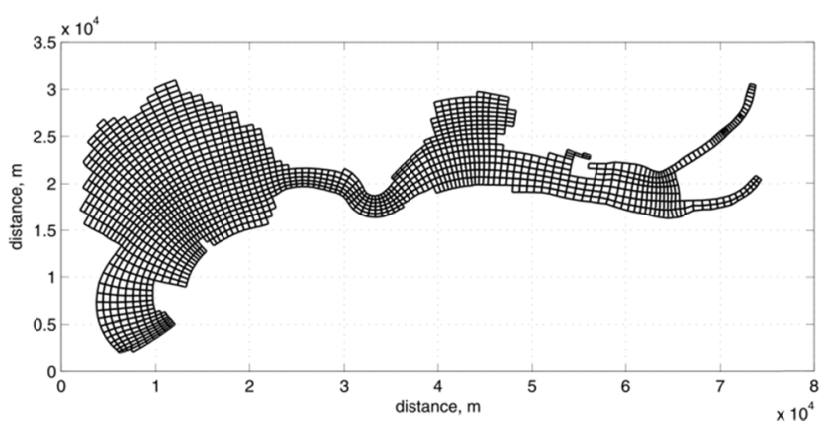

Figure 2. Numerical grid of model covering San Pablo Bay and Suisun Bay. The upper branch at the landward side represents the Sacramento River and the lower branch the San Joaquin River.

Figure 2 shows the model domain applied in the San Pablo Bay case study. A curvilinear grid is applied on the domain and the condition for a stable and accurate computation (Courant number $<10$ ) is met with a grid cell size of approximately 100 by $150 \mathrm{~m}$ and a time step of 2 minutes. Density currents and wave effects are included as well as 15 sigma layers describing the vertical grid distribution. The initial bathymetry is a measured (see Figure 3) and bed composition was derived as described by Van der Wegen et al. [2010].

The river discharge regime is modleled by a high river discharge 'wet' season and a low river discharge 'dry' season. This high level of schematization reduced river inflow to three practical 'tuning' parameters (i.e. duration of high discharge compared to low discharge and the magnitudes of the high and low river discharges). The landward river boundary conditions a derived from a larger 3D hydrodynamic model (Delft3D) covering a model domain ranging from the Delta to $20 \mathrm{~km}$ offshore including all sub-embayments of San Francisco Estuary [Van der Wegen et al. 2011]. In accordance with general observations salt concentration is set constant at zero at the landward boundary and at $31 \mathrm{psu}$ at the seaward boundary. Prevailing wind conditions are schematized by a diurnal sinusoidal signal varying from 0 at midnight to $7 \mathrm{~m} / \mathrm{s}$ at noon uniformly distributed over the domain. Every hour the SWAN model uses wind and hydrodynamic data from the flow calculation to generate a wave field and returns resulting adapted hydrodynamic parameters to the flow module. We apply 3 sand fractions modeled by Van Rijn transport formulation and five mud fractions modeled by the KronePatheniades formulation. Van der Wegen et al. [2011] provide further detail on the applied model formulations and schematizations.
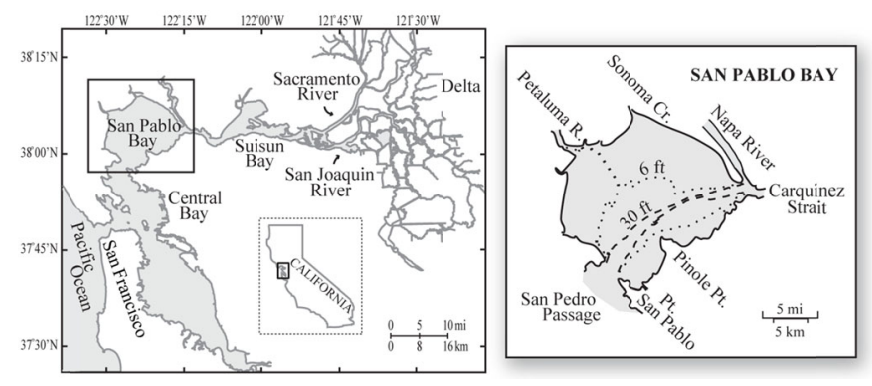

Figure 3. Location of San Pablo Bay in California

\section{MODEL RESULTS}

\section{Schematised model}

Figures 4 and 5 present model results after 100 days of morphodynamic development. Clearly one can observe the levee development occuring at the shoals. The channel become more shallow and the levee develop up to more than $0.5 \mathrm{~m}$ in height. There is a significant variation along the channel, because the western levees have developed first. Small channels have evolved at ebb. The channels are located irregular intervals to drain the shoals at ebb, but aslo enhance flooding efficiency. Sensitivity analysis has been carried out on D50, sediment transport fomulation, the bed slope factor, shoal dimensions (height, width and slope), height of mean water level and tidal amplitude, multiple sediment fractions including mud, application of wind and waves as well as channel curvature. 


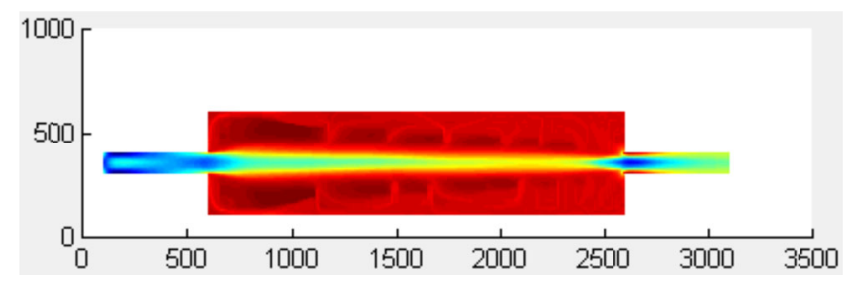

Figure 4. Model results: Bed level after 1000 days of morphodynamic development (blue refers to $8 \mathrm{~m}$ below mean water and dark red refers to1.5 $m$ above mean water).

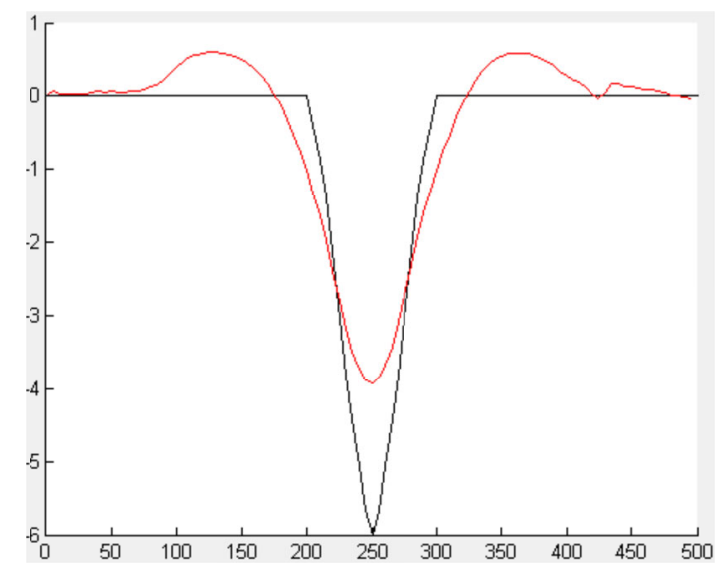

Figure 5. Model results: Mid domain bed level after 1000 days of morphodynamic development (black refers initial channel profile and red refers to profile after 1000 days).

\section{San Pablo Bay model}

Figure 6 shows the measured and modeled morphodynamimc developments of the San Pablo Bay model over two different 30 year periods. One may clearly observe the resemblence between modeled and measured erosion and sedimentation patterns. Also, the development of the channel banks is pronounced and well reproduced by the model. This gives confidence to further analyse the underlying conditions and processes that govern channel slope and levee development by means of the (detailed) data generated by the model.

\section{DISCUSSION AND CONCLUSION}

Closer analysis of the model results shows that levee development in the schematized model and slope accretion in the San Pablo Bay model both occur mainly during flooding of the shoal area. The explanation is twofold. Rising water levels flood the shoals and transverse flow velocities (perpendicular to the channel) reduce considerably while entering the shoals so that sediment settles. Secondly, sediment concentrations increase because sediment transported in the large channel water column now enters a smaller water depth. The higher sediment concentration enhances settling of sediment as well. Especially the San Pablo Bay case includes more complexity since water flows are not nicely alligned with the channel direction and much more processes are included such as wind waves and multiple sediment fractions. Accretion and erosion occur both during different phases of the tidal cycle. However, main accreation of the slopes occurs during flooding conditions. The process-baed modeling approach allows for a proper sensitivity analysis that enables to distinguish governing processes from secondary processes. For example, for the San Pablo Bay case study wind wave resuspension on the mudflats is necessary to let the westerly channel slopes accrete, whereas slope accretion on the easterly shoals is governed by dpoeistion during high river flow conditions.
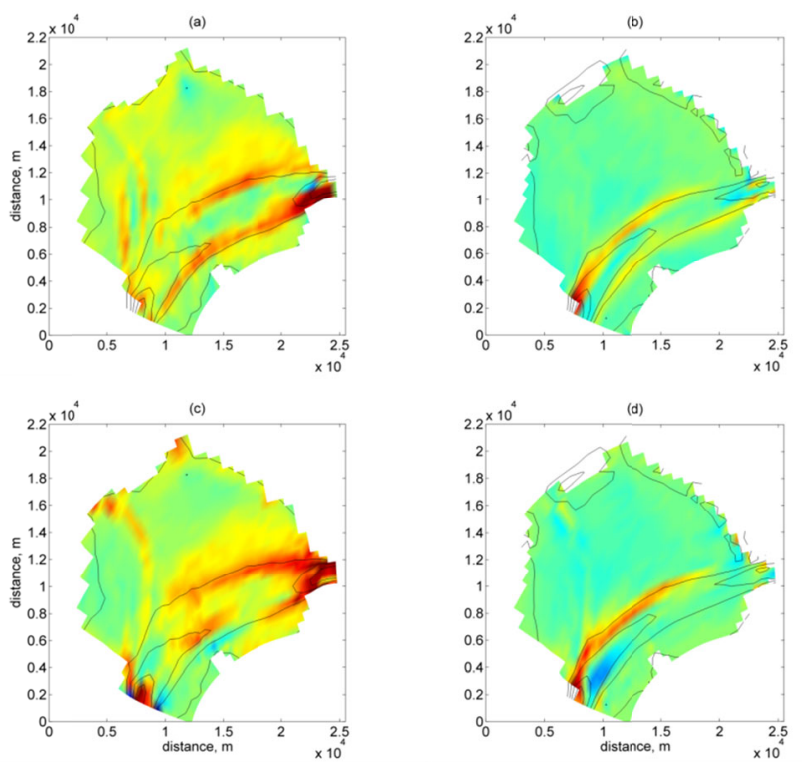

Figure 6. Erosion and sedimentation patterns (red is $5 \mathrm{~m}$ deposition and blue is $5 \mathrm{~m}$ erosion) measured $(a, b)$ and modeled (c,d) for 1856-1887 depositional period (a,c) and 1951-1983 erosional period $(b, d)$ (Figure is partly from Van der Wegen [2011]).

\section{ACKNOWLEDGEMENT}

The research is part of the US Geological Survey CASCaDE climate change project (CASCaDE contribution *). The authors acknowledge the US Geological Survey Priority Ecosystem Studies, CALFED and Deltares for making this research financially possible.

\section{REFERENCES}

Adams, PN, RL Slingerland \& ND Smith, 2004. Variations in natural levee morphology in anastomosed channel flood palin complexes. Geomorphology, 61: 127-142.

Booij, N., R.C. Ris and L.H. Holthuijsen, (1999), A thirdgeneration wave model for coastal regions, Part I, Model description and validation, J.Geoph.Research, 104, C4, 76497666)

Lesser, G.R., Roelvink, J.A. Van Kester, J.A.T.M., Stelling, G.S., (2004), Development and validation of a three-dimensional morphological model. Coastal Engineering 51, 883-915.

Brierley, GJ, RJ Ferguson \& KJ Woolfe, 1997. What is a fluvial levee? Sedimentary geology, 114: 1-9. 
Fildani, A., Normark, W.R., Kostic S. and Parker, G. (2006), Channel formation by flow stripping: large-scale scour features along the Monterey East Channel and their relation to sediment waves, Sedimentology, 53, pp 1265-1287 doi: 10.1111/j.13653091.2006.00812.x.

Jaffe, B. E., R. E. Smith, and A. C. Foxgrover (2007), Anthropogenic influence on sedimentation and intertidal mudflat change in San Pablo Bay, California: 1856-1983, Estuarine Coastal Shelf Sci., 73, 175-187, doi:10.1016/j.ecss.2007.02.017.

Normark, W.R., Piper, D.J.W., Posamentier, H., Pirmez, C., Migeon, S. (2002), Variability in form and growth of sediment waves on turbidite channel levees, Marine Geology 192, 23-58.

Perillo, GME \& OO Iribarne, 2003. Processes of tidal channel development in salt and freshwater marshes. Earth Surface Processes and Landforms, 28: 1473-1482.

Straub, K. M., and D. Mohrig (2008), Quantifying the morphology and growth of levees in aggrading submarine channels, J. Geophys. Res., 113, F03012, doi:10.1029/2007JF000896

Roelvink, J. A. (2006), Coastal morphodynamic evolution techniques, J. Coastal Eng., 53, 177-187.
Rowland, JC, WE Dietrich, G Day\& G Parker, 2009. Formation and maintenance of single-thread tie channels entering floodplain lakes: Observations from three diverse river systems. J. Geophysical Research, 114, F02013. (doi:10.1029/2008JF001073)

Temmerman, S.; Bouma, T.J.; Govers, G.; Wang, Z.B.; de Vries, M.B.; Herman, P.M.J. (2005). Impact of vegetation on flow routing and sedimentation patterns: Three dimensional modeling for a tidal marsh J. Geophys. Res. 110: F04019. dx.doi.org/10.1029/2005JF000301

Van der Wegen, M., Jaffe, B. E., and Roelvink, J. A., 2011. Process-based, morphodynamic hindcast of decadal deposition patterns in San Pablo Bay, California, 1856-1887, J. Geophys. Res., 116, F02008, doi:10.1029/2009JF001614.

Van der Wegen, M., A. Dastgheib, B.E. Jaffe, J.A. Roelvink, (2010), Bed composition generation for morphodynamic modeling: case study of San Pablo Bay in California, U.S.A.,Ocean Dynamics DOI: 10.1007/s10236-010-0314-2

Wells, JT, CE Adams, YA Park \& EW Frankenberg, 1990. Morphology, sedimentology and tidal channel processes on a high-tide-range mudflat, west coast of South Korea. Marine geology, 95: 111-130. 